\title{
EET Graduate Survey Results
}

\author{
William E. Cole, Jerome Tapper \\ School of Engineering Technology \\ Northeastern University
}

\begin{abstract}
In February 1997, The School of Engineering Technology at Northeastern University conducted a survey of the EET graduates from our program. The student sample included both Bachelors and Associates degree graduates, their employers, as well as some current part time students. A total of 133 responses to this survey were received and analyzed. This paper presents the responses to this survey and results of our analysis of these responses. These results include information on what our graduates are doing, what they find most important from their education, their pursuits of further education, their professional associations (including registration), and general implications these results have upon the EET curriculum.
\end{abstract}

\section{INTRODUCTION}

In February 1997, The school of Engineering Technology at Northeastern University conducted a survey of the EET graduates from our program. The main goal in this survey was to learn what skills our alumni found most and least important in the work place. Particular interest was the balance between technical knowledge and skills versus the process skills including problem solving and communications. Additionally, we wanted to probe two specific areas within the curriculum: graphics and computer usage.

The survey instruments are shown in the Appendix to this paper. Before creating these survey instruments, a literature search was conducted. From this search, a number of previous survey instruments were found and used as examples in creating these instruments. Some of the more useful examples include these references. ${ }^{1,2,3}$ The core of this survey is the second page: a series of 33 questions asking the respondent to rate each area on a scale of one to five in terms of importance on the job and secondly in terms of how well their education prepared them in each of these areas. In addition, the respondents were asked to respond to ten specific questions.

This survey instrument was sent to all our alumni graduating between 1990 and 1996 (approximately 1200 alumni in the combined areas of Mechanical Engineering Technology, Electrical Engineering Technology, and Computer Technology). These alumni included students who were recipients of either a Bachelor or an Associate degree. Thirteen percent of the alumni responded to the survey. Only responses from the EET alumni are reported in this paper while a second paper presents the results from the Mechanical Engineering Technology alumni. Alumni were requested to forward a second survey instrument to their supervisors. Unfortunately, only six responses were received from supervisors. Finally, a group of part time (evening) students 
were asked to complete a similar survey. The part time students are adult students who hold full time jobs. Hence, they are familiar with the workplace and know why they are going to school and what they hope the degree will do for their career. We wanted to learn how similar their responses were, compared to the alumni responses and if current evening students could provide a proxy for our alumni in future surveys. A total of 133 responses were received from EET students, including 74 alumni and 47 current part time students.

\section{RESULTS}

To characterize the respondents to the survey, their job titles are shown in Table 1.

Table 1: Current Job Titles of Respondents

$\begin{array}{cccc}\text { Title } & \begin{array}{c}\text { Alumni } \\ \text { Bachelors }\end{array} & \begin{array}{c}\text { Alumni } \\ \text { Associates }\end{array} & \text { Current } \\ (62) & \text { (7) } & \text { (50) }\end{array}$

\begin{tabular}{|l|c|c|c|}
\hline Engineer & 38 & 4 & 18 \\
\hline Manager & 7 & 2 & 3 \\
\hline Technician & 4 & 1 & 20 \\
\hline Other & 13 & & 9 \\
\hline
\end{tabular}

The first column of this table shows the job title of the respondent. The other columns show the number of respondents in each category that held that job title. The number at the top of the column (in parentheses) shows the number of respondents in each category. The totals in this and subsequent tables do not always add up to 133, since not all respondents answered all questions. Over Seventy percent of our graduates with a bachelors degree are functioning as either an engineer or manager and only six percent as technicians. Thus, it appears that our graduates are accepted in the workplace as engineers. This is an area or concern for technology educators who are concerned that the EET degree is not accepted in the workplace. In contrast to this observation, forty percent of our current students (who are not full time students) are working as technicians. Thus it appears that the bachelors degree is the "ticket" to the title of engineer or manager. It is also interesting that forty percent of our current students (who are not full time students) also have engineer or manager in their title. Thus it appears that they are continuing in school to preserve this position or to prepare themselves for further promotions.

The industrial sector employing the respondents is shown in Table 2. This table follows the same format as Table 1. The largest industry employing our students is Manufacturing by a wide margin. 
Table 2: Industries Employing the Survey Respondents

\section{Industry}

Alumni

(Bachelors)

(67)

\section{Alumni Current Total (Associates) \\ (8) \\ (55)}

\begin{tabular}{|l|c|c|c|c|}
\hline Manufacturing & 26 & 4 & 27 & 57 \\
\hline Service & 8 & 3 & 6 & 17 \\
\hline Utility & 8 & 1 & 3 & 12 \\
\hline Computer Software & 6 & & 3 & 9 \\
\hline Design/Development & 6 & & 1 & 7 \\
\hline Construction & 3 & & 1 & 4 \\
\hline Self & 2 & & & 2 \\
\hline Other & 3 & & 8 & 11 \\
\hline Unknown & 5 & & 6 & 11 \\
\hline
\end{tabular}

In furthering their education, 19 out of 65 of our bachelors degree alumni (30\%) are pursuing an advanced degree. The respondents were also asked about their professional affiliations. Fifteen of our bachelors alumni (23\%) and three of our Associates degree alumni (40\%) are members of IEEE. Additionally, respondents were members of ten other professional organizations with one or two members of each. Thus, it appears that our Bachelor degree alumni are accepted into the professional community, a concern with EET educators. In contrast, none of the current (part time) students were members of any professional organization.

As stated in the introduction, the core of this survey was the quantitative evaluation of the thirty three specific questions on the second page of the survey. The respondents were asked to rate on a scale of one to five the relative importance each of the categories was to their job, with five being the most important. The average response for all questions was 3.42 with a standard deviation of 1.22. Responses were averaged and the standard deviation calculated separately for each question and each category of recipient.

The first question asked what skills the respondents consider most important to their job. Table 3 shown below presents the survey responses in descending order from most important to least important. This table is ordered by the responses of Bachelor degree alumni in descending order. It is felt that this group (being the largest responding sample) would provide the best response of "skill importance" to their career. However, responses are similar between all groups. The areas of greatest importance are problem solving, accomplishing tasks within the organization, teamwork, oral communications, professional ethics, writing skills, and use of personal computer tools. 
Table 3: Most Important Skills

\begin{tabular}{|c|c|c|c|c|}
\hline Skill & $\begin{array}{c}\text { Alumni } \\
\text { (Bachelors) } \\
(\mathbf{6 5})\end{array}$ & $\begin{array}{c}\text { Alumni } \\
\text { (Associates) } \\
\text { (9) }\end{array}$ & Employer & Current \\
\hline
\end{tabular}

\begin{tabular}{|l|l|l|l|l|}
\hline Problem Solving & 4.67 & 4.67 & 5.00 & 4.29 \\
\hline Accomplishing Tasks & 4.62 & 4.33 & 4.83 & 4.09 \\
\hline Teamwork & 4.53 & 4.44 & 4.50 & 4.09 \\
\hline Oral & 4.51 & 4.44 & 4.50 & 4.11 \\
\hline Professional Ethics & 4.47 & 4.56 & 4.83 & 3.97 \\
\hline Writing & 4.44 & 4.67 & 4.50 & 4.08 \\
\hline Use of PC Tools & 4.31 & 4.56 & 4.00 & \\
\hline Managing People & 4.08 & 4.33 & 4.33 & 3.94 \\
\hline Design Process & & & 4.83 & 4.13 \\
\hline Visualizing Objects & & & 4.83 & \\
\hline Basic Electronics & & & 4.33 & 4.50 \\
\hline Using CAD Systems & & & 4.33 & \\
\hline Safety & & & 4.17 & \\
\hline Building Systems & & & 4.17 & \\
\hline Library Research & & & 4.17 & \\
\hline Digital Circuits & & & 4.00 & 4.39 \\
\hline Mechanics & & & 4.00 & \\
\hline
\end{tabular}

Differences between the averages are statistically significant $(2 \sigma)$ at a difference of 0.3 . Thus, these skills are all at a statistically similar level of importance. Not a single technical skill ranked within this highest priority list of skills. The rest of the items on this list are all in a statistically lower level of importance. Thus, functioning in the workplace appears to be more important than any technical skill. The results are similar between the other respondent categories. However, employers included the design process and visualizing objects within this highest priority category and current students included basic electronics. Numbers omitted from this table means that the response was not high enough to be included in one of the most important categories.

Results from this survey were similar to results from other surveys reported in the literature. For example, the New Jersey Institute of Technology(NJIT) survey found that their Principles of Management was the most useful course and writing was the most important skill on the job ${ }^{3}$. The Ohio State University(OSU) study found Communication and Problem Solving skills were rated higher than any technical skills ${ }^{4}$. Also the OSU study found that the highest ranked technical skills were in the computer and graphics $\operatorname{area}^{2}$. Additionally, a Purdue Focus group found communication skills and team work very important ${ }^{5}$. At Northeastern University we also asked our College of Engineering industrial advisory board to provide us with their perspective of the workplace of the $21^{\text {st }}$ century and what skills our graduates need to work in that 
environment. Again, responses to that question emphasized communications and problem solving skills ${ }^{6}$.

The second question asked what skills the respondents consider least important to their job. Table 4 shows the average survey responses in ascending order where the lowest numerical responses are considered to be the least important.

Table 4: Least Important Skills

Skill
Alumni (Bachelors) Alumni
Associates) (65)
(6)
(47)

\begin{tabular}{|l|c|c|c|c|}
\hline Differential Equations & 1.97 & 2.22 & 2.33 & \\
\hline Thermo/Fluids & 2.20 & 2.22 & & 2.53 \\
\hline Calculus & 2.37 & 2.67 & 2.50 & \\
\hline Materials & 2.50 & 2.67 & & 3.00 \\
\hline Visual Basic Programming & 2.60 & 2.78 & 2.33 & \\
\hline Statistics & 2.60 & & & 2.94 \\
\hline Mechanics & 2.69 & 2.33 & & \\
\hline Building Systems & 2.84 & & & 2.85 \\
\hline Drawing Tools & 2.85 & & & \\
\hline Manufacturing Processes & & 2.56 & 2.83 & \\
\hline Laboratory Skills & & 2.67 & & \\
\hline Library Research & & 2.33 & & \\
\hline C programming & & 2.89 & 2.17 & \\
\hline Unix Knowledge & & & 1.83 & \\
\hline
\end{tabular}

Math (Differential Equations, Calculus) and basic engineering technology skills (Thermo/Fluids, Materials) are low in importance to the respondents. This is consistent with the New Jersey Institute of Technology(NJIT) survey where Thermodynamics and Mathematics were singled out as the least helpful courses ${ }^{3}$. Thus, our alumni do not find these skills that we taught them important on the job. This finding is not shown as dominantly with the current students where we force them to use the mathematical skills in their courses. Thus, the university curriculum is influencing the results for this group.

Previous studies have also found similar results. In the Ohio State University(OSU) study, differential equations were found to be the least important technical skill in the survey instrument ${ }^{4}$. Similar results were also obtained by the New Jersey Institute of Technology(NJIT) survey. This survey singled out mathematical courses as being the least helpful in the curriculum ${ }^{3}$. 
It is also informative to examine the standard deviations of the responses to the thirty three questions (items 20 to 23) on the back of the survey (see Appendix A). Table 5 shows only the responses with the lowest standard deviation (less than 1.0).

Table 5: Smallest Standard Deviations

\begin{tabular}{|c|c|c|c|}
\hline Skill & $\begin{array}{c}\text { Alumni } \\
\text { (Bachelors) } \\
(\mathbf{6 5})\end{array}$ & $\begin{array}{c}\text { Alumni } \\
\text { (Associates) } \\
(9)\end{array}$ & Employer Current \\
\hline
\end{tabular}

\begin{tabular}{|l|c|c|c|c|}
\hline Accomplishing Tasks & 0.64 & & 0.41 & \\
\hline Problem Solving & 0.65 & 0.50 & 0.00 & 0.83 \\
\hline Oral & 0.67 & & 0.55 & 0.95 \\
\hline Writing & 0.75 & 0.71 & 0.55 & \\
\hline Teamwork & 0.78 & & 0.84 & \\
\hline Professional Ethics & 0.81 & 0.53 & 0.41 & \\
\hline Differential Equations & 0.96 & & & \\
\hline C Programming & & 0.60 & & \\
\hline Use of PC Tools & & 0.73 & & \\
\hline Visualizing Objects & & 0.78 & 0.41 & \\
\hline Knowledge of Workstations & & 0.83 & & \\
\hline Library Research Skills & & 0.87 & & \\
\hline Visual Basic Programming & & 0.97 & & \\
\hline Design Process & & & 0.41 & 0.99 \\
\hline Engineering Economics & & & 0.41 & \\
\hline Managing People & & & 0.52 & 0.96 \\
\hline Unix Knowledge & & & 0.75 & \\
\hline Basic Electronics & & & & 0.80 \\
\hline Digital Circuits & & & 0.89 \\
\hline Electrical Power Systems & & & 0.97 \\
\hline
\end{tabular}

The low standard deviations indicated in Table 5 demonstrates a consensus between respondents. Hence, all respondents tend to agree with the average response. Tables 3 and 4 respectively show that the skills rated as most important, as well as least important to the respondents career are agreed to by all respondents. The exception to this is the unimportance of Calculus.

To mirror Table 5, Table 6 shows the responses with the largest standard deviation. This indicates a lack of consensus in the average between the respondents. Hence, some respondents find the particular skill important and other respondents find it unimportant. Computer Programming, Laboratory Skills, Manufacturing Processes, Safety, and Design Process are high on this list. Thus, these skills are important to some respondents but not to others. 
Table 6: Responses with the Largest Standard Deviations
Skill
Alumni
(Bachelors)
Alumni
(Associates)
(65)
(9)
Employer
Current
(6)
(47)

\begin{tabular}{|l|l|l|l|l|}
\hline C Programming & 1.61 & & & \\
\hline Unix knowledge & 1.53 & 1.48 & & 1.33 \\
\hline Laboratory Skills & 1.52 & & 1.64 & \\
\hline Manufacturing Processes & 1.51 & & & \\
\hline Using CAD Systems & 1.50 & & & \\
\hline Safety & 1.49 & & & \\
\hline Visual Basic Programming & 1.49 & & & \\
\hline Design Process & 1.48 & 1.39 & & \\
\hline Visualizing Objects & 1.48 & & & \\
\hline Calculus & & 1.41 & & \\
\hline Materials & & 1.50 & 1.37 & \\
\hline Electrical Power Systems & & 1.60 & & \\
\hline Thermo/Fluids & & & 1.47 & \\
\hline Workstations Knowledge & & & 1.38 & \\
\hline Differential Equations & & & 1.37 & \\
\hline Statistics & & & 1.37 & \\
\hline Drawing Tools & & & & 1.27 \\
\hline Library Research Skills & & & & 1.27 \\
\hline
\end{tabular}

\section{CURRICULUM IMPLICATIONS}

The point of doing any survey, such as this, is to use the results to determine what is important and should be emphasized within the curriculum and what should receive less emphasis. This section of the paper will discuss the curriculum implications of this survey. Obviously, this is not the sole input to any curriculum revisions, but merely one of many inputs in determining what should be taught within the Electrical Engineering Technology curriculum.

The overwhelming conclusion from this survey, is that the curriculum needs to emphasize process skills rather than technical learning. These skills include problem solving, teamwork, and communications (both oral and written). One way to do this is to incorporate design projects within the technical classes: A group design project, with a final written report, requires the use (and hence learning) of all of these skills. A second opportunity to emphasize these skills is in laboratory reports. It is easy to fall into the mode of providing detailed directions for each 
laboratory experiment and to require individual written reports from each student. However, by providing only superficial directions and goals for the experiment, the students must develop their problem solving skills (how to do the experiment). Secondly, by requiring group reports, the students will develop their teamwork skills. Both of these activities also reinforce design and laboratory skills which are important to some of the students.

On the basis of this survey, design projects have been incorporated into many of our courses starting at the Freshman level with a course that introduces students to the "teamwork" concept of "we not I". Requiring students to understand and implement the "Engineering Design Process" in a group design project goes a long way in molding their interpersonal, communications and writing skills. Team ideas carry through in various laboratories where students are required to write professional laboratory reports that contain all the elements of a professionally written document where "English counts". Results have been very good and the students appreciate the changes as cited in a letter from a recent BSET graduate commending the program for helping better his position within his company by requiring him to write lab reports of such a high caliber.

Mathematics was singled out in this survey, as well as several others to be the least helpful course sequence in the curriculum ${ }^{3,4}$. We must, however, teach math to our students. Therefore, we should refocus our mathematical instruction to make it more beneficial to the students and useful to their careers. Possibly, by teaching more applications in the mathematics curriculum or moving more math topics into the technical course sequence, where we can make the math more interesting and show the students how to use math to solve problems.

Also pointed out by this study is the need to strengthen certain technical areas that are traditionally given only passing mention. These include ethics and safety. These are two topics that are generally acknowledged as being important. However, they are frequently only taught as auxiliary material within other courses. For example, the study of employers of Stevens Institute of Technology engineering undergraduates found deficiencies in the ethical training of the graduates $^{7}$. We need to consider dedicated courses in these topical areas.

\section{CONCLUSIONS}

Contrary to what we hear in educational circles, I am pleased to say that our graduates are being accepted within the professional community. A large fraction of our graduates serve in engineering or managerial capacity and are members of professional organizations.

The most important conclusion from this survey is that higher emphasis must be placed upon teaching process skills. These process skills include how to solve problems in teams and communicate with others. Thus our education must emphasize these process skills in addition to teaching specific technical material.

The results of the survey were very consistent between the four different groups responding. General conclusions drawn from the groups of Bachelor degree alumni, Associate degree alumni, 
Employers, and our current evening students are all consistent. Thus, for convenience, current evening students can be used as a proxy for the larger population in future surveys.

\section{REFERENCES}

1. Stanley, William D. and Verma, Alok K., "Long-Term Performance of Old Dominion University

Engineering Technology Graduates,” Proceedings of 1996 ASEE Annual Conference, Session 3247, 1996.

2. Britton, Robert R. et. Al., "Are We Preparing Engineering Students With the Right Skills in Engineering Graphics And Computer Training? A Survey,” Engineering Design Graphics Journal, Vol 58, No. 2, Spring 1994, p23.

3. Rockland, Ronald H., "Course Analysis Effectiveness Survey of BSET Graduates," Proceedings of the 1993 ASEE Annual Meeting, Session 1247, 1993.

4. $\quad$ Fentiman, Audeen W., et. al., “The First Two Years - Are Engineering Students Learning the Skills They Need?," Engineering Design Graphics Journal, Vol. 58, No. 2, 1994, p30.

5. Cooney, Elaine M. and Bowman, Michael, "Electronics Manufacturing Curriculum: What Industry Wants," 1996 ASEE Annual Conference Proceedings, Session 2563, 1996.

6. Soyster, Allen, "The Engineering Workplace in the $21^{\text {st }}$ Century," responses to the COE industrial advisory committee meeting, May 1997.

7. Keen, Peter A., "Undergraduate Engineering Skills Preparedness," Proceeding of the 1996 ASEE Annual Conference, Session 2242, 1996.

\section{WILLIAM E. COLE}

Dr. Cole received his Bachelors of Mechanical Engineering Degree from Stevens Institute of Technology and his Doctor of Philosophy from Pennsylvania State University. He has over twenty years of industrial experience developing industrial process equipment at the United Technologies Research Center and Thermo Electron Corp. Dr. Cole is now using this industrial experience to help educate the next generation of engineers.

\section{JEROME TAPPER}

Mr. Tapper received a Bachelor of Science Degree in Electrical Engineering from Northeastern University and will receive a Master of Science Degree in Information Systems also from Northeastern University in June of 1998. Mr. Tapper is a Registered Professional Engineer in the Commonwealth of Massachusetts with over twenty years of industrial experience in the areas of process control, circuit design and product development. 


\section{APPENDIX A}

\section{$\underline{\text { Alumni Survey Instrument Questionnaire }}$}

1. Your Current Job Title:

2. Your Current Employer:

3. Your Major at Northeastern University: CT

EET MET AERO
Part Time

MFG

4. Do You Feel that the Engineering Technology Program prepared you adequately for your career? (If NO, please explain) YES $\mathrm{NO}$

5. What professional organizations do you belong to?

6. Are you licensed or certified in your professional field? $\quad$ EIT PE

7. Have you obtained or are you currently working on an advanced degree? NO

8. What skill is most important to your current job?

9. A lack of preparation in what area has most limited your career?

Please circle the numbers that indicate how important each skill is to successful performance in your current position and how well Northeastern University prepared you in each of these areas.

Importance on Job

Unimportant

20.

Basic Engineering Skills

Calculus

Differential Equations

Statistics

Mechanics

Materials

Thermodynamics/Fluid Dynamics

Building Systems

Basic Electronics

Electrical Power Systems

Digital Circuits

Engineering Economics

Safety

m Manufacturing Processes

n Laboratory Skills

o Design

21. Basic Graphics Skills

$\begin{array}{ll}\text { a } & \text { Sketching } \\ \text { b } & \text { Visualizing Objects from 2D Drawings } \\ \text { c } & \text { Use of Drawing Tools } \\ \text { d } & \text { Use of CAD Systems } \\ \text { e } & \text { Use of Advanced CAD Analysis }\end{array}$

22. Computer Skills

a UNIX knowledge

b Knowledge of Workstations

Programming in C

Programming in Visual Basic

Use of PC Tools
Critical

$\begin{array}{lllll}\mathbf{1} & \mathbf{2} & \mathbf{3} & \mathbf{4} & \mathbf{5} \\ \mathbf{1} & \mathbf{2} & \mathbf{3} & \mathbf{4} & \mathbf{5} \\ \mathbf{1} & \mathbf{2} & \mathbf{3} & \mathbf{4} & \mathbf{5} \\ \mathbf{1} & \mathbf{2} & \mathbf{3} & \mathbf{4} & \mathbf{5} \\ \mathbf{1} & \mathbf{2} & \mathbf{3} & \mathbf{4} & \mathbf{5} \\ \mathbf{1} & \mathbf{2} & \mathbf{3} & \mathbf{4} & \mathbf{5} \\ \mathbf{1} & \mathbf{2} & \mathbf{3} & \mathbf{4} & \mathbf{5} \\ \mathbf{1} & \mathbf{2} & \mathbf{3} & \mathbf{4} & \mathbf{5} \\ \mathbf{1} & \mathbf{2} & \mathbf{3} & \mathbf{4} & \mathbf{5} \\ \mathbf{1} & \mathbf{2} & \mathbf{3} & \mathbf{4} & \mathbf{5} \\ \mathbf{1} & \mathbf{2} & \mathbf{3} & \mathbf{4} & \mathbf{5} \\ \mathbf{1} & \mathbf{2} & \mathbf{3} & \mathbf{4} & \mathbf{5} \\ \mathbf{1} & \mathbf{2} & \mathbf{3} & \mathbf{4} & \mathbf{5} \\ \mathbf{1} & \mathbf{2} & \mathbf{3} & \mathbf{4} & \mathbf{5} \\ \mathbf{1} & \mathbf{2} & \mathbf{3} & \mathbf{4} & \mathbf{5}\end{array}$

Preparation

Inadequate Superior

$\begin{array}{lllll}\mathbf{1} & \mathbf{2} & \mathbf{3} & \mathbf{4} & \mathbf{5} \\ \mathbf{1} & \mathbf{2} & \mathbf{3} & \mathbf{4} & \mathbf{5} \\ \mathbf{1} & \mathbf{2} & \mathbf{3} & \mathbf{4} & \mathbf{5} \\ \mathbf{1} & \mathbf{2} & \mathbf{3} & \mathbf{4} & \mathbf{5} \\ \mathbf{1} & \mathbf{2} & \mathbf{3} & \mathbf{4} & \mathbf{5} \\ \mathbf{1} & \mathbf{2} & \mathbf{3} & \mathbf{4} & \mathbf{5} \\ \mathbf{1} & \mathbf{2} & \mathbf{3} & \mathbf{4} & \mathbf{5} \\ \mathbf{1} & \mathbf{2} & \mathbf{3} & \mathbf{4} & \mathbf{5} \\ \mathbf{1} & \mathbf{2} & \mathbf{3} & \mathbf{4} & \mathbf{5} \\ \mathbf{1} & \mathbf{2} & \mathbf{3} & \mathbf{4} & \mathbf{5} \\ \mathbf{1} & \mathbf{2} & \mathbf{3} & \mathbf{4} & \mathbf{5} \\ \mathbf{1} & \mathbf{2} & \mathbf{3} & \mathbf{4} & \mathbf{5} \\ \mathbf{1} & \mathbf{2} & \mathbf{3} & \mathbf{4} & \mathbf{5} \\ \mathbf{1} & \mathbf{2} & \mathbf{3} & \mathbf{4} & \mathbf{5} \\ \mathbf{1} & \mathbf{2} & \mathbf{3} & \mathbf{4} & \mathbf{5}\end{array}$

23. Communication \& Problem Solving Skills

$\begin{array}{ll}\text { a } & \text { Writing Skills } \\ \text { b } & \text { Oral Skills } \\ \text { c } & \text { Problem Solving } \\ \text { d } & \text { Library Research Skills } \\ \text { e } & \text { Teamwork } \\ \text { f } & \text { Professional Ethics } \\ \text { g } & \text { Managing People } \\ \text { h } & \text { Accomplishing Tasks within an Organization }\end{array}$

Other(

$\begin{array}{lllll}\mathbf{1} & \mathbf{2} & \mathbf{3} & \mathbf{4} & \mathbf{5} \\ \mathbf{1} & \mathbf{2} & \mathbf{3} & \mathbf{4} & \mathbf{5} \\ \mathbf{1} & \mathbf{2} & \mathbf{3} & \mathbf{4} & \mathbf{5} \\ \mathbf{1} & \mathbf{2} & \mathbf{3} & \mathbf{4} & \mathbf{5} \\ \mathbf{1} & \mathbf{2} & \mathbf{3} & \mathbf{4} & \mathbf{5}\end{array}$

$\begin{array}{lllll}\mathbf{1} & \mathbf{2} & \mathbf{3} & \mathbf{4} & \mathbf{5} \\ \mathbf{1} & \mathbf{2} & \mathbf{3} & \mathbf{4} & \mathbf{5} \\ \mathbf{1} & \mathbf{2} & \mathbf{3} & \mathbf{4} & \mathbf{5} \\ \mathbf{1} & \mathbf{2} & \mathbf{3} & \mathbf{4} & \mathbf{5} \\ \mathbf{1} & \mathbf{2} & \mathbf{3} & \mathbf{4} & \mathbf{5}\end{array}$

25. What one or two Engineering Technology courses were most helpful in advancing your career goals?

26. What one or two Engineering Technology courses were least helpful in advancing your career goals? 


\section{APPENDIX A (continued)}

\section{Employer Survey Instrument Questionnaire}

1. Do you feel that the Engineering Technology Program prepared your employee adequately for his/her career? If no, please explain.

YES

NO

2. What skill is most important in our alumni's current job?

3. A lack of preparation in what area has (or will) most limit his/her career?

4. If you had the opportunity to recommend the Engineering Technology Program at Northeastern University, would you recommend it positively? YES NO

Please circle the numbers that indicate how important each skill is to successful performance in our alumni's current position and how well Northeastern University prepared him/her in each of these areas.

Importance on Job

20. Basic Engineering Skills

$\begin{array}{ll}\text { a } & \text { Calculus } \\ \text { b } & \text { Differential Equations } \\ \text { c } & \text { Statistics } \\ \text { d } & \text { Mechanics } \\ \text { e } & \text { Materials } \\ \text { f } & \text { Thermodynamics/Fluid Dynamics } \\ \text { g } & \text { Building Systems } \\ \text { h } & \text { Basic Electronics } \\ \text { i } & \text { Electrical Power Systems } \\ \text { j } & \text { Digital Circuits } \\ \text { k } & \text { Engineering Economics } \\ \text { l } & \text { Safety } \\ \text { m } & \text { Manufacturing Processes } \\ \text { n } & \text { Laboratory Skills } \\ \text { o } & \text { Design }\end{array}$

21. Basic Graphics Skills

$\begin{array}{ll}\text { a } & \text { Sketching } \\ \text { b } & \text { Visualizing Objects from 2D Drawings } \\ \text { c } & \text { Use of Drawing Tools } \\ \text { d } & \text { Use of CAD Systems } \\ \text { e } & \text { Use of Advanced CAD Analysis }\end{array}$

22. Computer Skills

$\begin{array}{ll}\text { a } & \text { UNIX knowledge } \\ \text { b } & \text { Knowledge of Workstations } \\ \text { c } & \text { Programming in C } \\ \text { d } & \text { Programming in Visual Basic } \\ \text { e } & \text { Use of PC Tools }\end{array}$

23. Communication \& Problem Solving Skills

$\begin{array}{ll}\text { a } & \text { Writing Skills } \\ \text { b } & \text { Oral Skills } \\ \text { c } & \text { Problem Solving } \\ \text { d } & \text { Library Research Skills } \\ \text { e } & \text { Teamwork } \\ \text { f } & \text { Professional Ethics } \\ \text { g } & \text { Managing People } \\ \text { h } & \text { Accomplishing Tasks within an Organizat }\end{array}$

$\begin{array}{ccccc}\text { Unimportant } & & & \text { C } \\ & & & & \\ \mathbf{1} & \mathbf{2} & \mathbf{3} & \mathbf{4} & \mathbf{5} \\ \mathbf{1} & \mathbf{2} & \mathbf{3} & \mathbf{4} & \mathbf{5} \\ \mathbf{1} & \mathbf{2} & \mathbf{3} & \mathbf{4} & \mathbf{5} \\ \mathbf{1} & \mathbf{2} & \mathbf{3} & \mathbf{4} & \mathbf{5} \\ \mathbf{1} & \mathbf{2} & \mathbf{3} & \mathbf{4} & \mathbf{5} \\ \mathbf{1} & \mathbf{2} & \mathbf{3} & \mathbf{4} & \mathbf{5} \\ \mathbf{1} & \mathbf{2} & \mathbf{3} & \mathbf{4} & \mathbf{5} \\ \mathbf{1} & \mathbf{2} & \mathbf{3} & \mathbf{4} & \mathbf{5} \\ \mathbf{1} & \mathbf{2} & \mathbf{3} & \mathbf{4} & \mathbf{5} \\ \mathbf{1} & \mathbf{2} & \mathbf{3} & \mathbf{4} & \mathbf{5} \\ \mathbf{1} & \mathbf{2} & \mathbf{3} & \mathbf{4} & \mathbf{5} \\ \mathbf{1} & \mathbf{2} & \mathbf{3} & \mathbf{4} & \mathbf{5} \\ \mathbf{1} & \mathbf{2} & \mathbf{3} & \mathbf{4} & \mathbf{5} \\ \mathbf{1} & \mathbf{2} & \mathbf{3} & \mathbf{4} & \mathbf{5} \\ \mathbf{1} & \mathbf{2} & \mathbf{3} & \mathbf{4} & \mathbf{5}\end{array}$

Critical

\section{5}

5

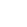

(2)

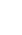

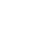

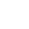

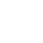

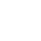

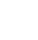

Inadequate

Preparation

$\begin{array}{llllllllll}\mathbf{1} & \mathbf{2} & \mathbf{3} & \mathbf{4} & \mathbf{5} & \mathbf{1} & \mathbf{2} & \mathbf{3} & \mathbf{4} & \mathbf{5} \\ \mathbf{1} & \mathbf{2} & \mathbf{3} & \mathbf{4} & \mathbf{5} & \mathbf{1} & \mathbf{2} & \mathbf{3} & \mathbf{4} & \mathbf{5} \\ \mathbf{1} & \mathbf{2} & \mathbf{3} & \mathbf{4} & \mathbf{5} & \mathbf{1} & \mathbf{2} & \mathbf{3} & \mathbf{4} & \mathbf{5} \\ \mathbf{1} & \mathbf{2} & \mathbf{3} & \mathbf{4} & \mathbf{5} & \mathbf{1} & \mathbf{2} & \mathbf{3} & \mathbf{4} & \mathbf{5} \\ \mathbf{1} & \mathbf{2} & \mathbf{3} & \mathbf{4} & \mathbf{5} & \mathbf{1} & \mathbf{2} & \mathbf{3} & \mathbf{4} & \mathbf{5}\end{array}$

\begin{tabular}{ccccc} 
Inadequate & & \multicolumn{2}{c}{ Superior } \\
& & & & \\
$\mathbf{1}$ & $\mathbf{2}$ & $\mathbf{3}$ & $\mathbf{4}$ & $\mathbf{5}$ \\
$\mathbf{1}$ & $\mathbf{2}$ & $\mathbf{3}$ & $\mathbf{4}$ & $\mathbf{5}$ \\
$\mathbf{1}$ & $\mathbf{2}$ & $\mathbf{3}$ & $\mathbf{4}$ & $\mathbf{5}$ \\
$\mathbf{1}$ & $\mathbf{2}$ & $\mathbf{3}$ & $\mathbf{4}$ & $\mathbf{5}$ \\
$\mathbf{1}$ & $\mathbf{2}$ & $\mathbf{3}$ & $\mathbf{4}$ & $\mathbf{5}$ \\
$\mathbf{1}$ & $\mathbf{2}$ & $\mathbf{3}$ & $\mathbf{4}$ & $\mathbf{5}$ \\
$\mathbf{1}$ & $\mathbf{2}$ & $\mathbf{3}$ & $\mathbf{4}$ & $\mathbf{5}$ \\
$\mathbf{1}$ & $\mathbf{2}$ & $\mathbf{3}$ & $\mathbf{4}$ & $\mathbf{5}$ \\
$\mathbf{1}$ & $\mathbf{2}$ & $\mathbf{3}$ & $\mathbf{4}$ & $\mathbf{5}$ \\
$\mathbf{1}$ & $\mathbf{2}$ & $\mathbf{3}$ & $\mathbf{4}$ & $\mathbf{5}$ \\
$\mathbf{1}$ & $\mathbf{2}$ & $\mathbf{3}$ & $\mathbf{4}$ & $\mathbf{5}$ \\
$\mathbf{1}$ & $\mathbf{2}$ & $\mathbf{3}$ & $\mathbf{4}$ & $\mathbf{5}$ \\
$\mathbf{1}$ & $\mathbf{2}$ & $\mathbf{3}$ & $\mathbf{4}$ & $\mathbf{5}$ \\
$\mathbf{1}$ & $\mathbf{2}$ & $\mathbf{3}$ & $\mathbf{4}$ & $\mathbf{5}$ \\
$\mathbf{1}$ & $\mathbf{2}$ & $\mathbf{3}$ & $\mathbf{4}$ & $\mathbf{5}$
\end{tabular}


24. Other(

$\begin{array}{lllll}1 & 2 & 3 & 4 & 5\end{array}$

$\begin{array}{lllll}1 & 2 & 3 & 4 & 5\end{array}$

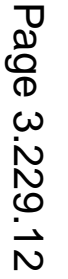




\section{APPENDIX A (continued)}

\section{Current Student(evening) Survey Instrument Questionnaire}

1. Your Name:

2. Your Current Job Title:

3. Your Current Employer:

4. Your Major at Northeastern University: CT $\quad$ EET $\quad$ MET $\quad$ AERO

5. Your anticipated Graduation Date:

6. Do You Feel that the Engineering Technology Program is preparing you adequately for your future?
(If NO, please explain on a separate page)
YES
NO

7. List one or two Engineering Technology courses that you feel were most helpful in advancing you career goals.

8. List one or two Engineering Technology courses that you feel were least helpful in advancing your career goals.

9. If you could make one change in the Engineering Technology program, what would you recommend ?

10. If you had the opportunity to recommend this program to a fellow worker, would you recommend it positively? YES

NO If not, why?

Please circle the numbers that indicate how important each skill is to successful performance in your current position and how well Northeastern University prepared you in each of these areas.

20. Basic Engineering Skills

Calculus

Differential Equations

Statistics

Mechanics

Materials

Thermodynamics/Fluid Dynamics

Building Systems

Basic Electronics

Electrical Laboratories

Electrical Power Systems

Digital Circuits

Engineering Economics

m Safety

n Manufacturing Processes

Laboratory Skills

Other (

21. Basic Graphics Skills

$\begin{array}{ll}\text { a } & \text { Sketching } \\ \text { b } & \text { Reading Drawings } \\ \text { c } & \text { Visualizing Objects from 2D Drawings } \\ \text { d } & \text { Preparing Drawings } \\ \text { c } & \text { Use of Drawing Tools } \\ \text { f } & \text { Use of CAD Systems } \\ \text { g } & \text { Use of Advanced CAD Tools } \\ \text { h } & \text { Other ( }\end{array}$

22. Computer Skills

$\begin{array}{lllllll}\text { a } & \text { Basic Computer Operation } & \mathbf{1} & \mathbf{2} & \mathbf{3} & \mathbf{4} & \mathbf{5} \\ \text { b } & \text { UNIX knowledge } & \mathbf{1} & \mathbf{2} & \mathbf{3} & \mathbf{4} & \mathbf{5} \\ \text { c } & \text { Knowledge of Workstations } & \mathbf{1} & \mathbf{2} & \mathbf{3} & \mathbf{4} & \mathbf{5} \\ \text { d } & \text { Programming in C } & \mathbf{1} & \mathbf{2} & \mathbf{3} & \mathbf{4} & \mathbf{5} \\ \text { e } & \text { Programming in Visual Basic } & \mathbf{2} & \mathbf{3} & \mathbf{4} & \mathbf{5} \\ \text { f } & \text { Use of PC Tools } & \mathbf{1} & \mathbf{2} & \mathbf{3} & \mathbf{4} & \mathbf{5} \\ \text { g } & \text { Other ( } & \mathbf{1} & \mathbf{2} & \mathbf{3} & \mathbf{4} & \mathbf{5}\end{array}$

Importance on Job

Preparation

$\begin{array}{ccccc}\text { Unimportant } & & & & \text { Critic } \\ & & & & \\ \mathbf{1} & \mathbf{2} & \mathbf{3} & \mathbf{4} & \mathbf{5} \\ \mathbf{1} & \mathbf{2} & \mathbf{3} & \mathbf{4} & \mathbf{5} \\ \mathbf{1} & \mathbf{2} & \mathbf{3} & \mathbf{4} & \mathbf{5} \\ \mathbf{1} & \mathbf{2} & \mathbf{3} & \mathbf{4} & \mathbf{5} \\ \mathbf{1} & \mathbf{2} & \mathbf{3} & \mathbf{4} & \mathbf{5} \\ \mathbf{1} & \mathbf{2} & \mathbf{3} & \mathbf{4} & \mathbf{5} \\ \mathbf{1} & \mathbf{2} & \mathbf{3} & \mathbf{4} & \mathbf{5} \\ \mathbf{1} & \mathbf{2} & \mathbf{3} & \mathbf{4} & \mathbf{5} \\ \mathbf{1} & \mathbf{2} & \mathbf{3} & \mathbf{4} & \mathbf{5} \\ \mathbf{1} & \mathbf{2} & \mathbf{3} & \mathbf{4} & \mathbf{5} \\ \mathbf{1} & \mathbf{2} & \mathbf{3} & \mathbf{4} & \mathbf{5} \\ \mathbf{1} & \mathbf{2} & \mathbf{3} & \mathbf{4} & \mathbf{5} \\ \mathbf{1} & \mathbf{2} & \mathbf{3} & \mathbf{4} & \mathbf{5} \\ \mathbf{1} & \mathbf{2} & \mathbf{3} & \mathbf{4} & \mathbf{5} \\ \mathbf{1} & \mathbf{2} & \mathbf{3} & \mathbf{4} & \mathbf{5} \\ \mathbf{1} & \mathbf{2} & \mathbf{3} & \mathbf{4} & \mathbf{5}\end{array}$

Critical

5

5

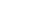




\section{APPENDIX A (continued)}

\section{Current Student(evening) Survey Questionnaire Instrument(continued)}

$\begin{array}{ll}\text { 23. } & \text { Communication \& Problem Solving Skills } \\ \text { a } & \text { Writing Skills } \\ \text { b } & \text { Oral Skills } \\ \text { c } & \text { Problem Solving } \\ \text { d } & \text { Library Research Skills } \\ \text { e } & \text { Teamwork } \\ \text { f } & \text { Professional Ethics } \\ \text { g } & \text { Managing People } \\ \text { h } & \text { Accomplishing Tasks within an Organization } \\ \text { i } & \text { Other ( } \\ & \\ \text { 24. } & \text { Basic Design Skills } \\ \text { a } & \text { Design Process } \\ \text { b } & \text { Concurrent Design } \\ \text { c } & \text { Design for Manufacture } \\ \text { d } & \text { Other ( }\end{array}$

\begin{tabular}{|c|c|c|c|c|}
\hline & \multicolumn{4}{|c|}{ Importance on Job } \\
\hline \multicolumn{4}{|c|}{ Unimportant } & \\
\hline 1 & 2 & 3 & 4 & 5 \\
\hline 1 & 2 & 3 & 4 & 5 \\
\hline 1 & 2 & 3 & 4 & 5 \\
\hline 1 & 2 & 3 & 4 & 5 \\
\hline 1 & 2 & 3 & 4 & 5 \\
\hline 1 & 2 & 3 & 4 & 5 \\
\hline 1 & 2 & 3 & 4 & 5 \\
\hline 1 & 2 & 3 & 4 & 5 \\
\hline $\mathbf{1}$ & 2 & 3 & 4 & 5 \\
\hline
\end{tabular}
Preparation
Inadequate
Superior

Critical

$\begin{array}{lllll}\mathbf{1} & \mathbf{2} & \mathbf{3} & \mathbf{4} & \mathbf{5} \\ \mathbf{1} & \mathbf{2} & \mathbf{3} & \mathbf{4} & \mathbf{5} \\ \mathbf{1} & \mathbf{2} & \mathbf{3} & \mathbf{4} & \mathbf{5} \\ \mathbf{1} & \mathbf{2} & \mathbf{3} & \mathbf{4} & \mathbf{5}\end{array}$

$\begin{array}{lllll}\mathbf{1} & \mathbf{2} & \mathbf{3} & \mathbf{4} & \mathbf{5} \\ \mathbf{1} & \mathbf{2} & \mathbf{3} & \mathbf{4} & \mathbf{5} \\ \mathbf{1} & \mathbf{2} & \mathbf{3} & \mathbf{4} & \mathbf{5} \\ \mathbf{1} & \mathbf{2} & \mathbf{3} & \mathbf{4} & \mathbf{5} \\ \mathbf{1} & \mathbf{2} & \mathbf{3} & \mathbf{4} & \mathbf{5} \\ \mathbf{1} & \mathbf{2} & \mathbf{3} & \mathbf{4} & \mathbf{5} \\ \mathbf{1} & \mathbf{2} & \mathbf{3} & \mathbf{4} & \mathbf{5} \\ \mathbf{1} & \mathbf{2} & \mathbf{3} & \mathbf{4} & \mathbf{5} \\ \mathbf{1} & \mathbf{2} & \mathbf{3} & \mathbf{4} & \mathbf{5}\end{array}$

$\begin{array}{lllll}\mathbf{1} & \mathbf{2} & \mathbf{3} & \mathbf{4} & \mathbf{5} \\ \mathbf{1} & \mathbf{2} & \mathbf{3} & \mathbf{4} & \mathbf{5} \\ \mathbf{1} & \mathbf{2} & \mathbf{3} & \mathbf{4} & \mathbf{5} \\ \mathbf{1} & \mathbf{2} & \mathbf{3} & \mathbf{4} & \mathbf{5}\end{array}$

